\title{
Simulation of grid connected photovoltaic system using MATLAB/ Simulink
}

\author{
Ranu Verma, Prof. Kamlesh Gupta
}

Department of Elec. \& Electronics Engg., IES IPS Academy, Indore, M.P., India

\begin{abstract}
In this paper, a whole simulation model of grid connected $P V$ system with the practically of harmonics compensation is introduced during the simulation. The simulation model of grid connected PV system embrace a $P V$ array, a dc to dc buck boost converter and a dc to ac inverter. Grid connected PV system is electricity generating solar system that is connected to the utility grid. Within the world, energy sources just like fossil fuels and nuclear reaction area unit wide used for electrical power generation. However burning fossil fuels and nuclear area unit wide used for electrical power generation. we tend to get $I-V \& P-V$ characteristics of the model. These are often desired by mathematical equation that is nonlinear.
\end{abstract}

Keywords-Grid connected PV systems, DC-DC buck boost converter, $D C$ to $A C$ inverter, MPPT.

\section{INTRODUCTION}

Now a days the demand of electrical power in increasing day by day however the presence of fossil fuels square measure towards the tip. Therefore it's time to realize to seek out to search out find otherwise to get the ability typically it is conjointly tough to transmit power to the remote and craggy places that squares measure isolate for the most generating station. So as to boost energy potency and power quality problems the employment of cell energy generation system mistreatment wind and solar sources. No pollution is emitted i.e. $100 \%$ environment friendly.

Comparing with others renewable energy sources. Solar power is that the largest contributors to world energy fir its clean and unlimited offer characteristics photovoltaic power generation could be a quite renewable energy technology that has sustain development potential. Additionally it's one amongst the world's quickest growing industries. PV power generation refers to victimisation electrical phenomenon semiconductor materials and electrical phenomenon impact to convert solar power in to electricity energy.

A solar PV module may be a assortment of solar cells, principally connected serial. There combos of solar cells offer higher power than single cells. The solar power conversion into electricity takes places in an exceedingly conductor that's referred to as electric cell. A electric cell may be a unit that delivers solely an explicit quanttaptaity of electric power. So as to use solar electricity for sensible devices, that need a specific voltage or current for operation, variety of solar cells need to be connected along to make a electrical device, conjointly referred to as a electrical phenomenon (PV) modules.

The primary part of grid - connected PV system is power conditioning unit (PCU). The PCU converts the DC power made by the PV array into AC power as per the voltage and power quality needs of the utility grid. A bi-directional interface is formed between the PV system AC output circuit and electrical utility network, generally at associate degree on-site distribution panel or entranceway. This permits the AC power made by the PV system output is bigger than the on-site load demand. Star panels area unit solely a vicinity of a whole PV scheme.

Solar modules area unit the guts of the system and area unit typically referred to as the facility generators. For PV systems the need to operate in the dead of night or throughout the amount of weather condition the storage of energy area unit needed, the batteries for electricity storage area unit required. The output of a PV module depends on daylight intensity and cell temperatures, thus element that condition the $\mathrm{DC}$ (direct current) output and deliver it to batteries, grid, and/or load area unit needed for a sleek operation of the PV system.

A system cell incorporates solid state tangency invented from a semiconductor material (usually silicon). In dark, the IV characteristic of a cell has associate degree exponential characteristics kind of like that of a diode. But once the solar power (photons) his on the cell, energy bigger than the band gap energy of the semiconductor, and release electrons from the atoms in the semiconductor material, creating electron-hole pairs. They are exploitation grid system for implementation of electrical phenomenon systems needs interfacing power converters between the PV arrays and therefore the grid. In grid connected PV system DC-DC 
power converter that's accustomed operate the PV arrays at the utmost wall plug. and DC-AC power converter to interconnect the electrical phenomenon system to the grid.

A grid connected solar PV system could be a sort of electrical converter that converts electrical energy electricity from PV module into AC. Once the PV system is connected to the grid, it will transfer the additional energy to the grid when fulfilling the native demand.

\section{MATHEMATICAL MODEL FOR A PHOTOVOLTAIC CELL}

PV module represents the basic power conversion unit of a PV generator system. The output characteristics of a PV module depend upon the solar isolation, the cell temperature and therefore the output voltage of the PV module. A photovoltaic cell is essentially a tangency fictitious in an exceedingly skinny wafer of semiconductor. The radiations of solar power are often directly reborn to electricity through electrical phenomenon impact. Being exposed to the daylight, photons with energy larger than the band gap energy of the semiconductor creates some electron -hole pairs proportional to the incident irradiation.

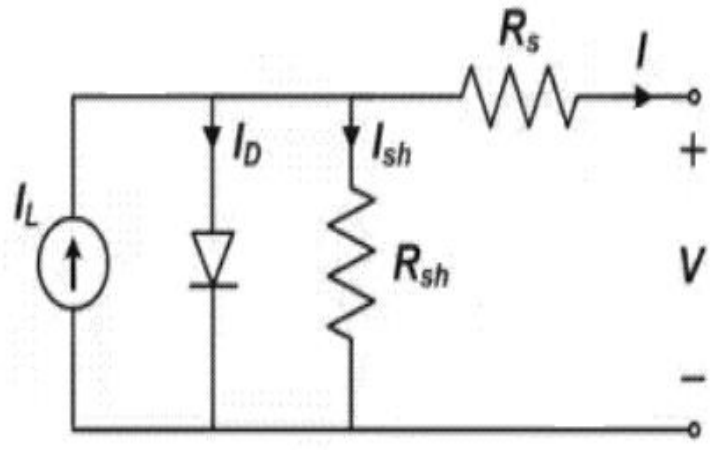

Fig. 1: Equivalent circuit of a photovoltaic cell

The current supply $I_{p h}$ represents the cell photocurrent. $R_{s h}$ and $R_{s}$ area unit the intrinsic shunt and series resistance of the cell. Sometimes the worth of $R_{s h}$ is incredibly massive which of $R_{S}$ is incredibly little. Therefore they'll be neglected to modify the analysis PV cells area unit classified in larger units referred to as PV modules that area unit additional interconnected in an exceedingly parallelseries configuration to create PV arrays.

The governing equation for this equivalent circuit is.

$$
I=I_{L}-I_{D}-I_{S H} \ldots .(1)
$$

Here, $I_{L}$ represents the total current of the cell. And $I_{L}$ represents the light generated current of the cell. In this equivalent circuit of photovoltaic cell, the equation for the diode is given by

$$
I_{D}=I_{O}\left[\exp \left(\frac{\mathrm{V}+\mathrm{IR}_{\mathrm{s}}}{\mathrm{nV}_{\mathrm{T}}}\right)-1\right] \ldots(2)
$$

In equation (2), $V_{T}$ is the diode ideality factor,

$$
V_{T}=k T_{C / q} \cdots
$$

Where,

$\mathrm{K}$ is the Boltzmann's constant $\left(1.381^{*} 10^{\wedge-23} \mathrm{~J} / \mathrm{K}\right)$ and the $\mathrm{q}$ is the electric charge, the value of $\mathrm{q}$ is $\left(10602^{*} 19^{\wedge-19} \mathrm{C}\right)$.

The short circuit current of the photovoltaic cell

$$
I_{s h}=\left(V+I_{R s} / R_{s h}\right)
$$

Put the value of equation (2), (3), (4) in equation (1) and we get the complete equation for the single diode model photovoltaic equivalent circuit.

$$
I=I_{L}-I_{O}-\left[\exp \left(\frac{\mathrm{V}+\mathrm{IR}_{\mathrm{s}}}{\mathrm{nV}_{\mathrm{T}}}\right)-1\right]-\frac{V+I R_{S}}{R_{S h}} \ldots \ldots
$$

In thus equation there are following parameter namely light current, series resistances, diode reverse saturation current, and diode ideality factor.

In the photovoltaic system the cells are connected in series and parallel. And all cell working in terms of temperature \& irradiation. The equation for generated current and voltage for the module is

$$
\begin{aligned}
I_{\text {module }} & =I_{\text {cell }} \\
V_{\text {module }} & =N_{s} \times V_{\text {cell }}
\end{aligned}
$$

The single diode equation for the photovoltaic array or modules becomes

$$
\begin{aligned}
& I_{M}=I_{L}-I_{O}\left[\exp \left(\frac{V_{M}+I_{M} N_{S} R_{S}}{n N_{S} V_{T}}\right)-1\right] \\
& \frac{V_{M}+I_{M} N_{S} R_{S}}{n N_{S} V_{T}} \ldots \text { (6) }
\end{aligned}
$$

Current (I) - voltage (V), power (P) - voltage (V) curve of a photovoltaic cell is shown in fig:

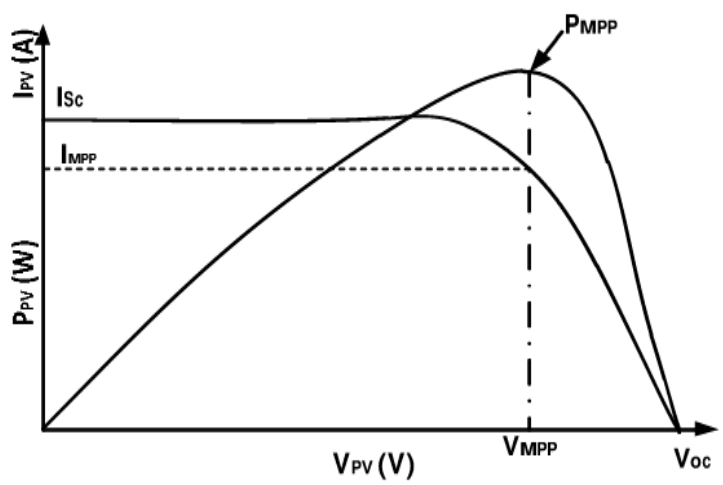

Fig.2: $P-V \& I-V$ characteristics of $P V$ cell 


\section{SIMULATION OF THE PHOTOVOLTAIC SYSTEM IN MATLAB/ SIMULINK SOFTWARE}

Grid connected PV system consists of PV plant, PV plants converts the daylight into DC power, and an influence acquisition unit that converts the DC power to AC power. The generated $\mathrm{AC}$ power injected into the grid and/or utilize by native masses through the filter. In some cases the PV system is combined with storage devices that improve the supply of the ability. The PV Plant consists of PV cell and it's organized serial and parallel combination to produce the required DC voltage and current.

Grid connected PV system consists of PV array, buck boost DC-DC converter, DC-AC inverter and distribution panel.

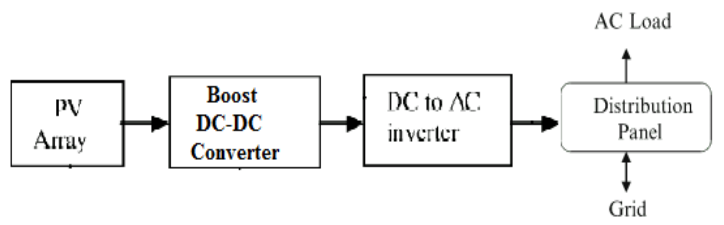

Fig.3: Grid connected PV system using MATLAB

\section{A .Simulation model of $P V$ array}

The PV array consists of PV cell and it organized serial and Parallel combination to Provide the required DC voltages and current. Commonly PV cell is created from element semiconductor and every element cell generates $0.6 \mathrm{v}$ the everyday. PV module used for simulation in shown in figure.

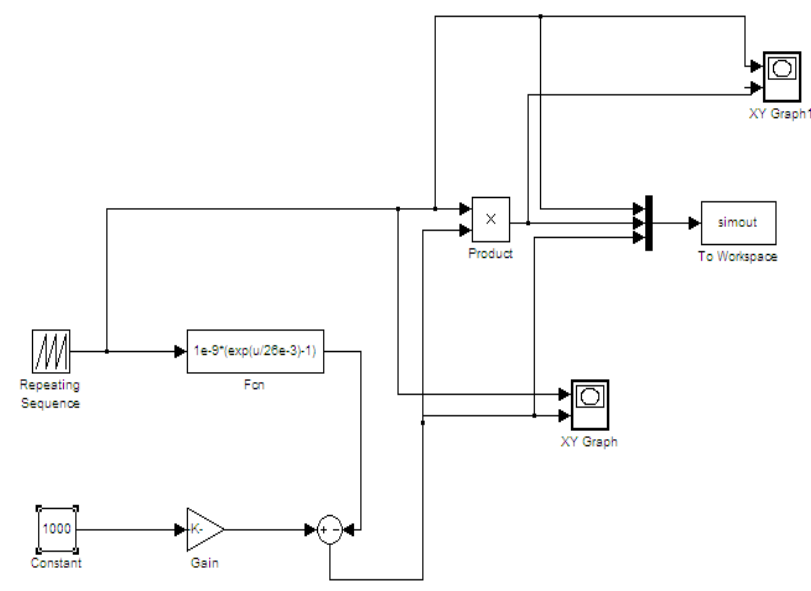

Fig.4: Siimulink model of PV array

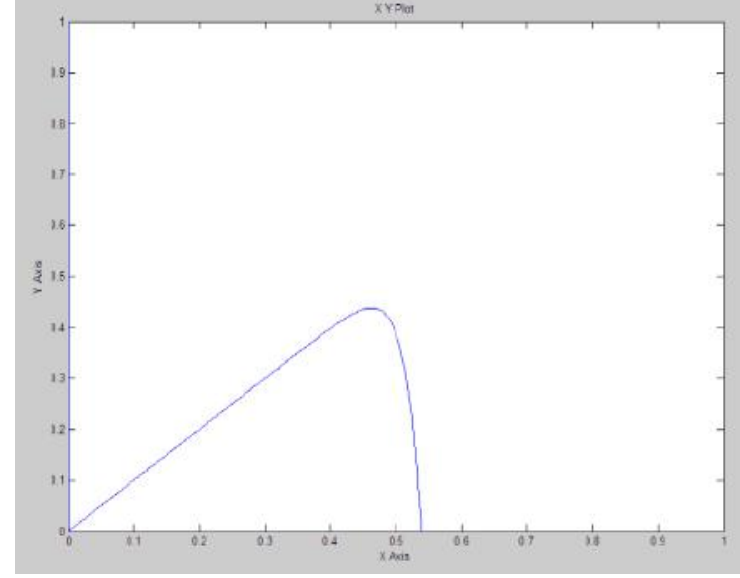

Fig.5: P-V characteristics of solar model

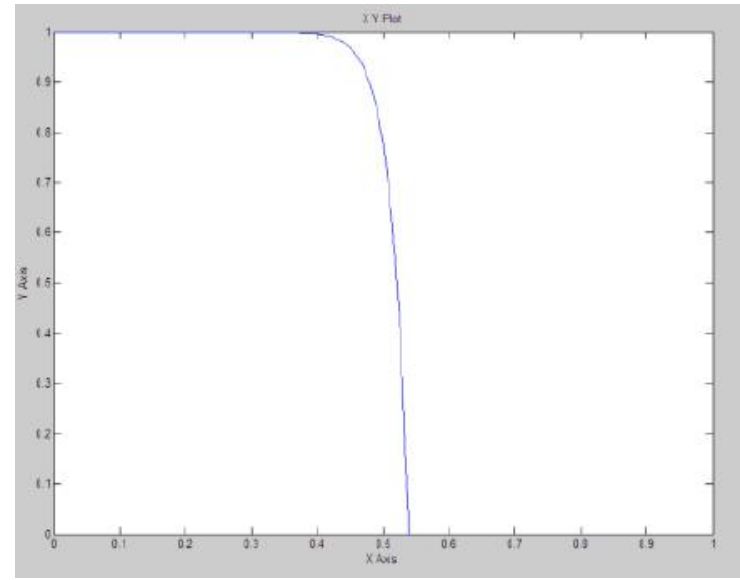

Fig.6: I-V characteristics of solar model

\section{B. Model of DC-DC buck boost converter}

The DC -DC converter works in buck mode once switch S1 is operated and switch S2 is continuously off mode. once S1 is closed offer voltage seems across the load, and by the time inductance stores the energy. currently once is opened, the hold on energy with the inductance freewheels is through load and diodes D1, D2. For operational in boost mode, switch $\mathrm{S} 1$ is kept continuously in ON mode and S2 is operated. Once S2 is closed, inductance L stores energy and S2 is opened, the provision voltage seems across the load and therefore the energy within the inductance seems because the additive energy to the load, therefore boost operations is performed.

Designing of $\mathrm{L}$ and $\mathrm{C}$ is a very important half for each software package and hardware implementation as a result of each buck and boost operation depends on the energy of inductance. 


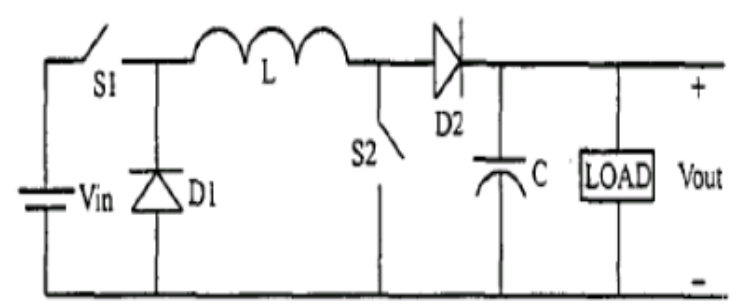

Fig.7: DC-DC buck boost converter

C. Simulink model of buck converter

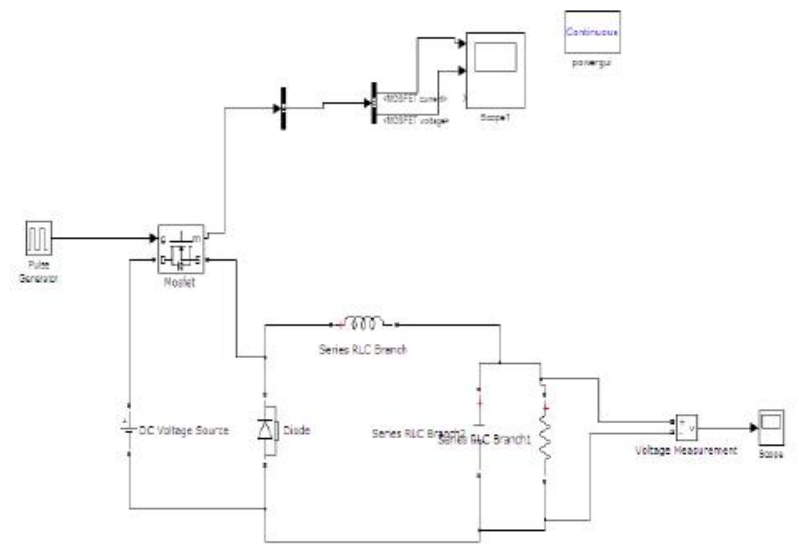

Fig.8: Buck converter using MATLAB

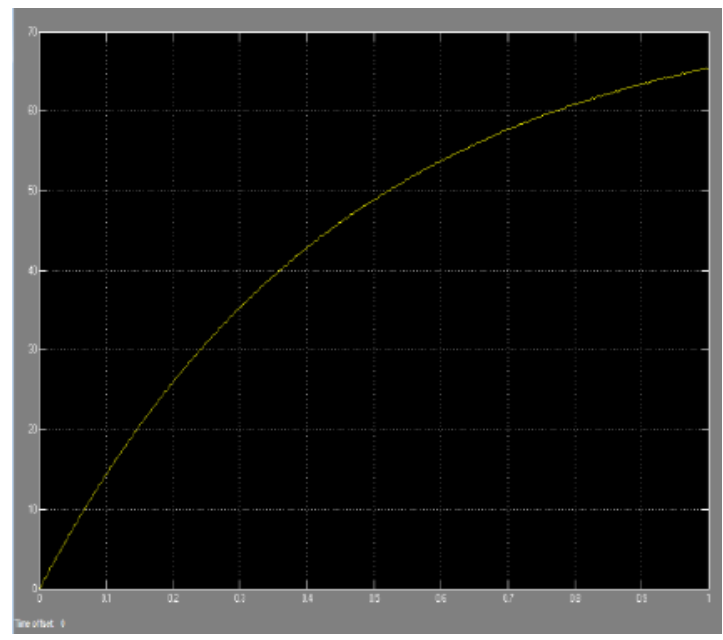

Fig.9: Simulation waveform of buck converter

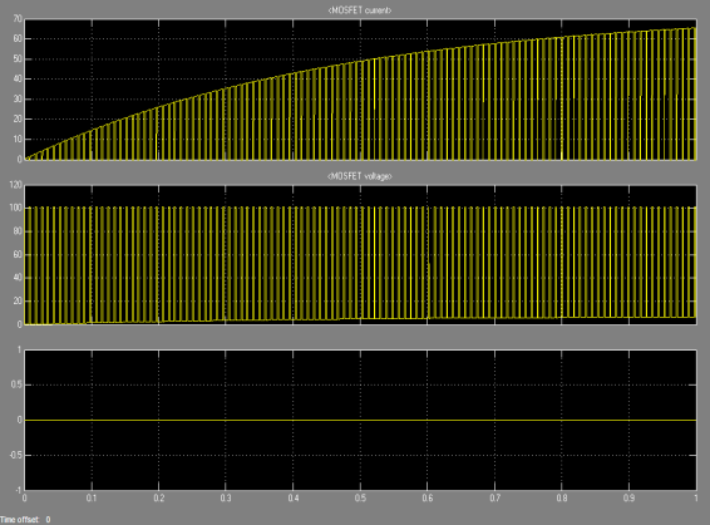

Fig.10: Simulation waveform of buck converter

D. Simulink of boost converter

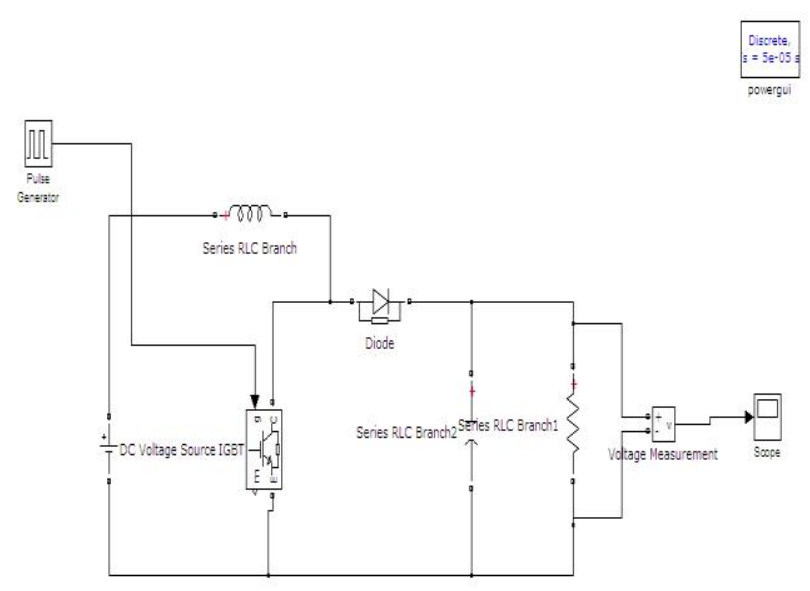

Fig.11: Simulink model of boost convert

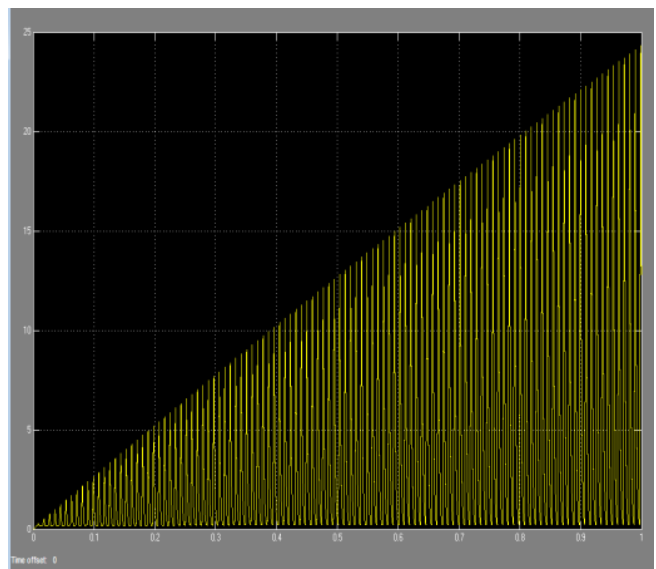

Fig.12: Simulation waveform of boost converter

E.Inverter modelling

In grid connected PV system inverter are used for interfacing the utility grid .DC-AC electrical inverter 
generates $\mathrm{AC}$ output current with $\mathrm{AC}$ grid voltage. and balance the typical power delivery from the PV array to the grid. electrical inverter or power electric inverter may be a device that converts the DC supply to AC supply. Inverters are utilized in a large vary of applications, from little switched power provides for a laptop to electrical utility applications to bulk power.

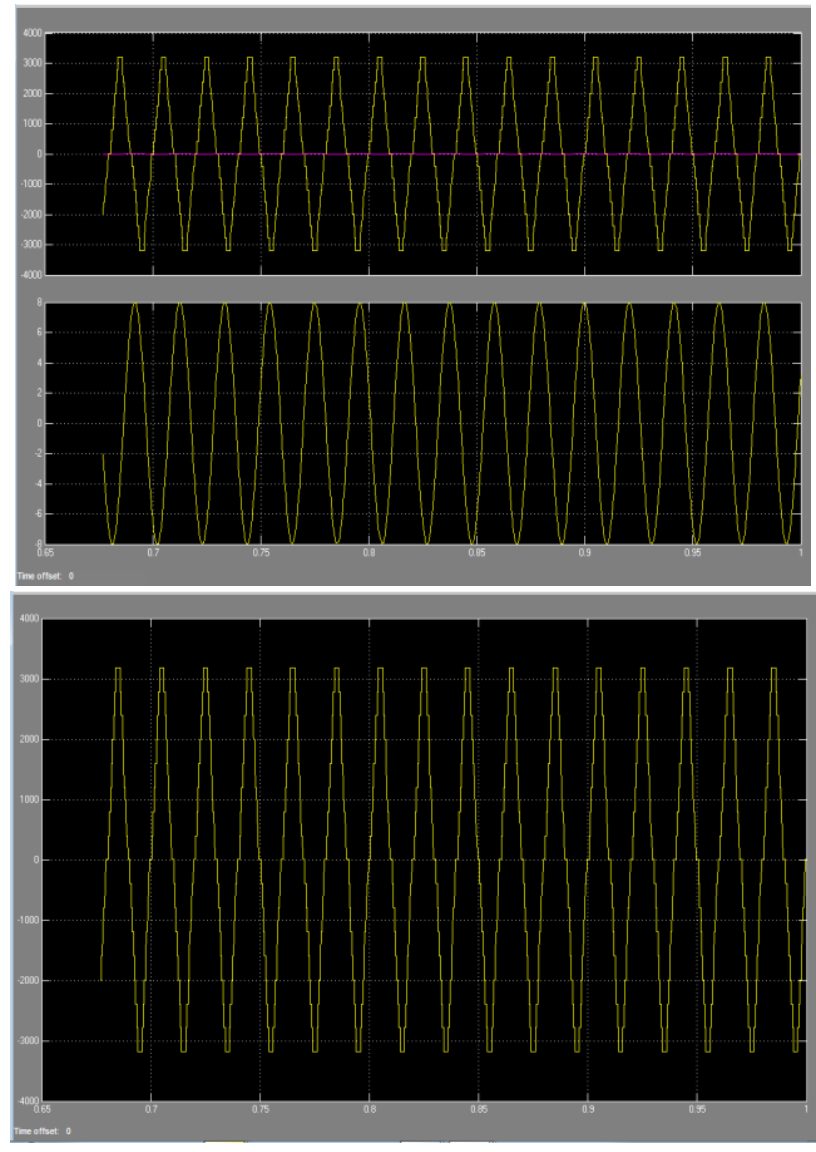

Fig.13: Simulation waveform of multilevel inverter

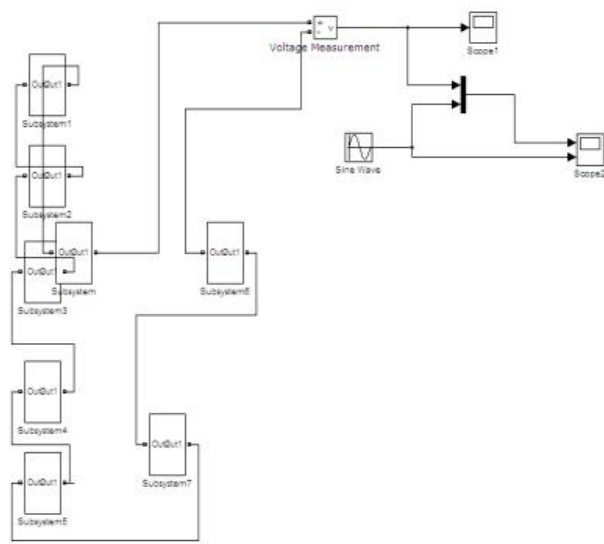

Fig.14: Simulation model of multilevel inverter

\section{F. MPPT}

The maximum power which will be delivered by a PV panel depends greatly on the simulation level and therefore the operative temperature. The weather change operation of $\mathrm{PV}$ system to vary most of the days. there are two methods of MPPT control. Perturb and observe method Increment conductance method.

\section{CONCLUSION}

In this Paper, to construct a PV grid connected system, variety of parameters needs to be taking under consideration and to be optimized so as to attain most power generation. solar PV system is employed just for grid connected electricity to control residential appliance, busssiness instrumentality electricity, lightning for all the kinds of building. Moreover, this study shows that the sun irradiance at increase thus increase the PV panel output power than increase the load demand.

PV model has the power to extend the potency of the system. this may be possible In future the theoretical result so obtain is compared with practical results associated an observation are created by however share result differ with theoretical result.

\section{REFERENCES}

[1] Santosh S. Raghuwanshi ${ }^{1}$, Kamlesh Gupta ${ }^{2}$,"Modelling Of a Single-Phase Grid-Connected Photovoltaic System Using MATLAB /Simulink", IEEE International Conference on Compute, Communication abd Control (IC4-2015).

[2] Jevrai Selvaraj, Nasraudin A. Rahim, “ Multilevel Inverter For Grid - connected PV system Employing Digital PI controller" , IEEE Transactions On Industrial Electronics, Vol. 56, No. 1, pp. 149- 158, 2009.

[3] Renewable Energy Policy Network for the 21st Century (REN21), "Renewable 2010 Global Status Report”, Myrzik, J.M.A., Calais, M., String and module integrated inverters for single phase grid connected photovoltaic system- a review, IEEE Power technology conference proceedings, Vol. 2, Page (5): S, pp.,2003.

[4] Deutsche Gesellschaftflir Technische Zusammenarbeit (GTZ) Gmb H, pp. 19, 2010.

[5] Huan-Liang Tsai, Ci-Siang Tu, Yi-Jie Su, "Development of Generalized Photovoltaic Model Using MATLAB/SIMULINK", Proceedings of the 
World Congress on Engineering and Computer

Science WCECS, San Francisco, USA, 2008.

[6] K. Topfer "Decard on isation of energy supply- central challenge for mankind" Clean Power from Deserts, The DESERTEC concept for energy, Water and climate security, White Book- 4th addition, Feb 2009.

[7] S. Leva, D. Zaninelli, Technical and Financial Analysis for Hybrid Photovoltaic Power Generation Systems, WSEAS Transactions on Power Systems, vol.5, no.1, May 2006, pp.831-838

[8] Savita Nema., R.K. Nema, Gayatri Agnihotri, "MATLAB/Simulink based study of photovoltaic cells/ modules/ array and their experimental verification", Internaioal Journal of Energy and Environment, vol. 1, No. 3, pp. 487-500,2010.

[9] Peng Lei, Yaoyu Li, member, ieee, and john e. seem, member, ieee "sequential esc-based global mppt control for photovoltaic array with variable shading", ieee transactions on sustainable energy, vol. 2 , no. 3 , july 2011

[10] M. G. Molina, and P. E. Mercado "Modeling and Control of Grid-connected PV Energy Conversion System used as a Dispersed Generator".978-14244-2218-0/08/@2008 IEEE

[11] Rakesh $\mathrm{R}^{1}$, Kannan $\mathrm{S} \mathrm{A}^{2}$, joy ${ }^{3}$, Kamala Devi $\mathrm{V}^{4}$,Prof.(Dr).Jayaraju $\mathrm{M}^{5}$., "Modelling and Analysis of MPPT Techniques for Grid Connected PV Systems" ,International Journal of Innovative Research In Electrical, Electronics And Control Engineering Vol. 2, issue 2, February 2014.

[12] Pritam Chowdhury ${ }^{1}$, Indrajit Koley ${ }^{2}$, Sougata Sen $^{3}$ Dr. Pradip Kumar Saha ${ }^{4}$, Dr. Gautam Kumar Panda ${ }^{5}$, "Modelling, Simulation and Control Of a Grid Connected Non Conventional Solar Power Generation System Using MATLAB", International Journal of Advanced Research in Electrical, Electronics and Instrumentation Engineering, Vol. 2', Issue 4, April 2013. 